\title{
Mango, Orange and Mandarin Peels Oleoresins to Prepare Natural and Healthy Instant Flavor Drinks
}

\author{
Mohamed R. Masoud and Eshak M. El-Hadidy ${ }^{*}$ \\ Food Technol. Research Inst., Agric. Research Center, Giza-Egypt
}

Received: $7 / 5 / 2017$

\begin{abstract}
Mango and citrus are major processed fruits in Egypt that results in large quantities of wastes and byproducts rich in various bioactive components such as water soluble and insoluble antioxidants and essential oils. Therefore, the objective of this study was to produce instant flavor drinks from oleoresins which obtained from fruit industry wastes (mango, orange and mandarin peels). Fruit peels are natural sources for dietary antioxidants and flavor. Mango, orange and mandarin peels industrial by-products contains many nutritionally and economically valuable components. These by-products from juice processing industries have significant exploitation potential. Therefore, the present study carried out on different instant flavor drinks which were prepared as mango, orange and mandarin peels oleoresin in 20, 4060,80 and $100 \mathrm{mg} / 100 \mathrm{~g}$ formulas to produce natural and healthy instant fruit peels flavor drinks compared to commercial products. These formulas evaluated for physico-chemical properties, antioxidants contents and their activities, volatile oil fractions and sensory evaluation. The obtained results indicated that antioxidant activity of mandarin peels oleoresin due to it is high phenolic compounds content $(50.51 \pm 2.41 \mathrm{mg} / \mathrm{g})$ and vitamin $\mathrm{C}(1.30 \pm 0.06$ $\mathrm{mg} / \mathrm{g})$. While, total flavonoids contents $(5.66 \pm 0.21 \mathrm{mg} / \mathrm{g})$ for mango peels oleoresin showed the second level for tested peels oleoresin antioxidant activity, also mango oleoresin has high content of in carotenoids $(12.53 \pm 0.43 \mathrm{mg} / \mathrm{g})$. Mandarin peels which have the significant content of volatile oil $(1.92 \pm 0.23 \mathrm{~g} / 100 \mathrm{~g})$, comparing to orange and mango oleoresin peels. Mango peels oleoresin has higher content in $\alpha$-pienene, terpinolene, myrcene and $\beta$-pienene than other fractions $(12.82,3.14,2.30$ and $1.54 \%$, respectively) Also, the major compound in orange then mandarin peels oleoresin was limonene (85.80 and $52.67 \%$, respectively). Camphor content has highest content in orange peels oleoresin (3.62\%). The most important aroma characteristic in mandarin peels oleoresin were 1,8-cineol (13.31\%) followed by $\gamma$ terpinene $(11.02 \%)$ then E- $\beta$-ocimene $(6.52 \%)$. Orange peels oleoresin has the highest antioxidant activity by DPPH method (from 54.20 to $73.00 \%$ ) in gradual concentrations followed by mango peels oleoresin (from 46.24 to $55.82 \%$ ) then mandarin peels oleoresin (from 33.92 to $52.02 \%$ ). These data are due to that orange peels oleoresin is rich in limonene and camphor, as well as carotenoids, flavonoids and vitamin C. Aroma in mandarin formula showed the highest one and that was due to the quantity of volatile oil and quality of some volatile oil compounds. Mango and orange peels oleoresin formulas gave also the highest evaluation in sensory acceptability which has been shown for the aroma and flavor results may be due to the highest contents in flavonoids and carotenoids and volatile oil components. Therefore, the use of mango, orange and mandarin oleoresins as natural flavors is better than commercial synthetic flavorings.
\end{abstract}

Keywords: Fruit peels, oleoresin, physico-chemical properties, natural flavor, antioxidants content, sensory evaluation

\section{INTRODUCTION}

Oleoresins are the concentrated liquids form plants containing volatile oil. They are obtained from plant by extraction with aqueous and non-aqueous solvents followed by removal of the solvent by evaporation (Chen and Huang, 2016). The advantages of oleoresins, easy to stored and transported, more stable when heated, more economical to use, easier to control for quality and cleaner than the equivalent ground spices, free from contamination, concentrated form reduces storage space and bulk handling and transport requirements and Longer shelf life due to minimal oxidative degradation or loss of flavor.

By-products remaining after fruits processing have been a problem due to high transportation costs and limited availability of landfills, as these by-products have no commercial value, they are often disposed unscrupulously. Improper disposal of mango peel waste may appreciably increase the environmental pollution due to its rapid decay, eventually becoming a source of insect multiplication. A high level of biological oxygen demand (BOD) and chemical oxygen demand (COD) in mango peel waste create a further problem in disposal (Puligundla et al., 2014).
Agroindustrial residue, such as seeds and peels represents about $50 \%$ of the raw process fruit (Orozco et al., 2014). Orange peel represents approximately 30-40 $\mathrm{g} / 100 \mathrm{~g}$ of the fresh fruit weight (Manjarres-Pinzon et al., 2013).

By-products from citrus fruits contains large amounts of high added value compounds and show a variety of valuable biologically active compounds in the citrus by-products (polyphenols, carotenoids and essential oils). The polyphenols and carotenoids are known to have numerous health benefits, mostly attributed to their antioxidant activity. It is important to note that the total content of polyphenols is higher in citrus peels, which is commonly discarded (Abd Elghfar et al., 2016). Also, essential oils are common in peels, which is a natural source of volatile substances. These uses of by-products therefore shows sustainable environmental benefits combined with increased economic gains as well as the production of nutrition food that will improve the lives of consumes.

Fruit peels are natural sources for dietary antioxidants and flavor. In order to explore the potential of fruit wastes as natural resources of bioactive compounds, the antioxidant potency and total phenolic

\footnotetext{
*Corresponding author e-mail: emgelhadidy1973@gmail.com
}

Volume 4 (1): 11-18 
contents (TPC) of lipophilic and hydrophilic components in wastes of orange and mandarin were evaluated (Casquete et al., 2015). Traditionally Mangifera indica has medicinal application. Many phenolic compounds have been detected in mango peels, barks, puree concentrate, leaves, pulps and seed kernels. Also, fresh mango peel contains significant amount of moisture $(70 \%)$ and it's rich in pectin, cellulose, hemicelluloses, lipids, proteins, flavonoids and carotenoids (Ajila et al., 2007).

It is well established that polyphenol which is rich in its fractions in peel extract could be used as natural antioxidants and functional food or feed supplements (Berardini et al., 2005). Mango peel is a rich source for phenolic compounds, which exhibit antioxidant activity (Palmeira et al., 2012). The major phenolic compounds present in mango peel extract are reported to be syringic acid, quercitin, mangiferin pentoside and ellagic acid (Ajila et al., 2010). Peels are good source of mangiferin (C-glucosyl xanthone), a heat-stable and pharmacologically active phytochemical. In a study, yogurt fortified with supplementation of $10 \%$ of mango peel powder showed a good texture, flavour and color characteristics and exhibited one month shelf life without adding preservatives (Ruiz et al., 2011).

Adewole et al. (2014) observed that the use of citrus peel as an economically valuable source of highadded value compounds as it contains a significant various flavonoids, carotenoids, dietary fiber, polyphenols, ascorbic acid and essential oil.

The aroma is one of the most significant and decisive parameters of quality in the selection of a product. Aroma compounds are present in raw foods in free volatile form and also as nonvolatile precursors such as substituted cysteine sulfoxides, thioglycosides, glycosides, carotenoids and cinnamic acid derivatives (Solis-Solis et al., 2007). The sugar moieties of glycosidically-bound aroma volatiles, which have been reported in mango, are $\gamma$-terpenyl- $\beta$-D- glucopyranosides, $\gamma$-terpenyl-6-o-rutinosides and $\gamma$ terpenyl-6-o-(-L-arabinofuranosyl)- $\beta$-D-glucopyranosides. Also, Aroma compounds (aglycones) can be released from glycosidically-bound compounds by enzymatic or chemical reactions during maturation, storage, industrial pretreatment/processing (Wetungu et al., 2015). Mango varieties differ in the amount and type of flavor compounds present which is dependent on their place of origin, major and minor volatile components with the latter being the key player in their aroma.

Commercial instant flavor drinks in local market contained thickeners (sodium carboxy methyl cellulose and gum Arabic), colors (Titanium dioxide, tartrazine, sunset yellow, Allura red), sweetener (aspartame and acesulfame potassium), flavors contain soya, phenylalanine and other components. Therefore, this formula not be used for patients having phenyl ketone urea, bean allergens, pregnant and lactating women and children under 3 years (Tuormaa, 1994). Thus, this study aimed produce natural and health product in mango, orange and mandarin peels oleoresin. Also, valorization of mango, orange and mandarin peels through different routes not only can increase the profitability of fruit processing industries, but also help reduce environmental pollution.

\section{MATERIALS AND METHODS}

Mango (Mangifera indica L.), bitter orange (Citus aurantium L.) and mandarin or tangerine (Citrus rectulata $\mathrm{L}$.) peels were collected in company producing juices in $6^{\text {th }}$ October city, Egypt, then to be ready for oleoresin extraction.

Oleoresin preparation

Fresh peels samples extracted by Soxhlet extraction with ethanol used by the manufacturer. Distill of ethanol completely using high vacuum towards the end. This commercial method was applied as Indian Standard (IS 7826:2003).

Formula preparation

Table (1): Formulas constituents (g/100g on dry weight basis) contained oleoresin peels compared to commercial products

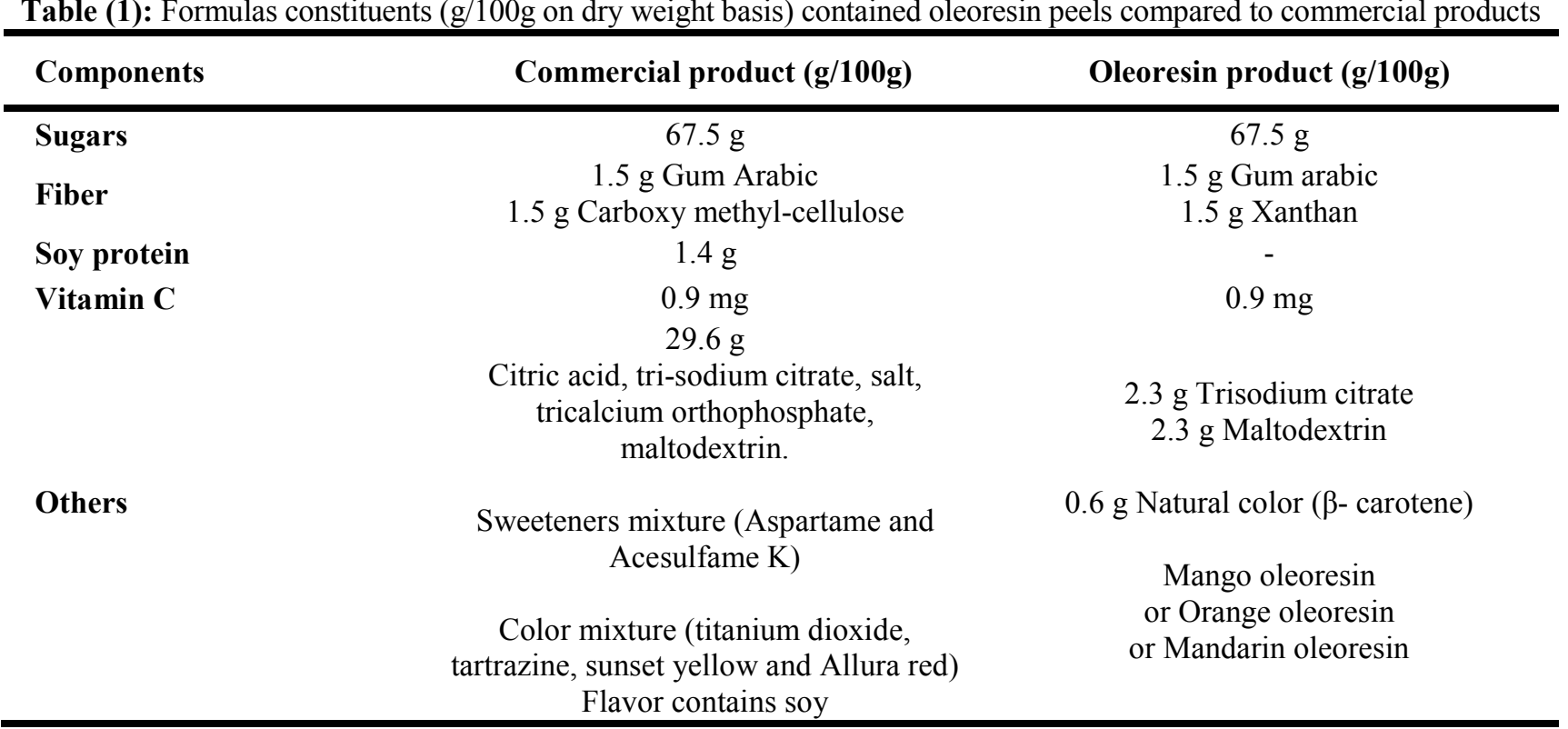




\section{Physicochemical analysis}

The $\mathrm{pH}$ of the mango, orange and mandarin peels oleoresin were measured using a $\mathrm{pH}$ meter (HANNA, $8417 \mathrm{H}$, Italy). Moisture and total acidity (as citric acid) was determined by AOAC method (2000). Total sugars was determined with phenol-sulphuric acid method according to Masuko et al. (2005). The Total soluble solids (TSS) value of the oleoresins products were recorded by using rafractometer has range of $0-100^{\circ}$ Brix (Bellingham-Stanley Lt., England). In each treatment, three readings were taken and their average value was expressed in ${ }^{\circ}$ Brix.

\section{Antioxidants content and its activity determination}

Total polyphenolic contents were measured using Folin-Ciocalteu method described by Boligon et al. (2009). Also, total flavonoids content as rutin was determined by Pharmacopeia (1989). While, carotenoids as $\beta$-carotene was determined according to Nagata and Yamashita (1992). Ascorbic acid was determined according to the methods of Klein and Perry (1982). Volatile oils were determined by International Standard Organization method (ISO 6571: 2009).

The antioxidant activity of the oleoresin peels were evaluated by using the 1,1diphenylpicrylhydrazyl (DPPH) assay described by Yen and Chen (1995).

\section{Essential oil fractionation by GC.MS}

$\mathrm{GC}$-flame ionization detection (FID) analyses were performed on a Shimadzu system. Separations were performed on $30-\mathrm{m} \times 0.25-\mathrm{mm}$ i.d. $\times 0.25-\mu \mathrm{m}$ film thickness column. The temperature program was as follows: $50^{\circ} \mathrm{C}$ to $250^{\circ} \mathrm{C}$ at $3^{\circ} \mathrm{C} / \mathrm{min}$. The injection volume was $1.0 \mu \mathrm{L}$, pressure was $102 \mathrm{kPa}$ at constant pressure, and carrier gas was Helium at $30 \mathrm{~cm} / \mathrm{s}$ of average linear velocity. The split ratio was 1:100. The detector was set at $280^{\circ} \mathrm{C}$ (Mondello et al., 2004).

\section{Sensorial evaluation}

The sensory attributes of color, sweetness, aroma, flavor, consistency, and overall acceptability were evaluated by 10 panelists when resolve $25 \mathrm{~g}$ (for each formula)/1 liter water (Ranganna, 2005).

\section{Statistical analysis}

The data were statistically analyzed using SPSS program version 19 (2000). Means and standard deviations were determined using descriptive statistics.
Differences were tested for significance by using the ANOVA procedure, using a significance level of $\mathrm{P}<0.05$.

\section{RESULTS AND DISCUSSIONS}

The yields of oleoresin on fresh weight basis for the three investigated waste peels are detrained and the results are shown in Table (2). Orange peels were the highest one in the yield of oleoresin $(70.34 \mathrm{mg} / \mathrm{g})$, then mango peels $(46.26 \mathrm{mg} / \mathrm{g})$, while mandarin was the lowest one $(24.82 \mathrm{mg} / \mathrm{g})$.

Table (2): Mango, orange and mandarin peels and its oleoresins yield on fresh weight basis

\begin{tabular}{lccc}
\hline Items & Mango & Orange & Mandarin \\
\hline $\begin{array}{l}\text { Peels yield } \\
\%\end{array}$ & $17.50 \pm 2.52$ & $22.70 \pm 1.14$ & $30.25 \pm 3.25$ \\
$\begin{array}{l}\text { Oleoresin } \\
\text { yield mg/g }\end{array}$ & $46.26 \pm 3.50$ & $70.34 \pm 8.55$ & $25.82 \pm 2.81$ \\
\hline Values are mean & & & \\
\hline
\end{tabular}

Values are means \pm Standard deviation of triplicates

Data in Table (3) show moisture, $\mathrm{pH}$, titratible, acidity, total sugars and total soluble solid contents in mango, orange and mandarin peels oleoresin formulas compared with commercial products. Results indicated that, commercial products have highest contents in moisture $(2.60,2.54$ and $2.52 \%$, respectively) compared to mango, orange and mandarin peels oleoresins products $(2.21,2.33$ and $2.24 \%$, respectively). Moisture contents in oleoresin products were also highest in orange followed by mandarin then mango peels oleoresin. While, the $\mathrm{pH}$ value was the highest in commercial mango compared to mandarin and orange products $(4.20,3.91$ and 3.88 , respectively) than natural oleoresin products. In parallel, $\mathrm{pH}$ value was decrease gradually in mango, orange then mandarin peels oleoresin (4.28, 4.10 and 4.02), respectively. In contrast, titratible acidity was increase gradually in mango, mandarin then orange peels oleoresin $(0.41,0.38$ and 0.37 , respectively) formulas.

Table (3): Physico-chemical properties of mango, orange and mandarin peels oleoresin formulas compared to commercial products (On dry weight basis).

\begin{tabular}{lccccc}
\hline Items & $\begin{array}{c}\text { Moisture } \\
\mathbf{( \% )}\end{array}$ & $\mathbf{p H}$ & $\begin{array}{c}\text { Total titratible } \\
\text { acidity } \\
\text { (as citric acid) }\end{array}$ & $\begin{array}{c}\text { Total sugars } \\
\mathbf{( \% )}\end{array}$ & $\begin{array}{c}\text { Total soluble solid } \\
\left({ }^{\mathbf{0}} \mathbf{B r i x}\right)\end{array}$ \\
\hline Commercial & $2.60 \pm 0.06$ & $4.20 \pm 0.07$ & $0.42 \pm 0.01$ & $80.70 \pm 0.09$ & $96.00 \pm 0.19$ \\
Mango formula & $2.21 \pm 0.04$ & $4.28 \pm 0.10$ & $0.41 \pm 0.02$ & $78.10 \pm 0.12$ & $93.20 \pm 0.21$ \\
Commercial & $2.54 \pm 0.05$ & $3.88 \pm 0.03$ & $0.38 \pm 0.02$ & $82.00 \pm 0.07$ & $97.36 \pm 0.21$ \\
Orange formula & $2.33 \pm 0.04$ & $4.10 \pm 0.09$ & $0.37 \pm 0.01$ & $75.13 \pm 0.10$ & $9 r .40 \pm 0.24$ \\
Commercial & $2.52 \pm 0.04$ & $3.91 \pm 0.08$ & $0.39 \pm 0.02$ & $81.55 \pm 0.011$ & $89.46 \pm 0.18$ \\
Mandarin formula & $2.24 \pm 0.04$ & $4.02 \pm 0.10$ & $0.38 \pm 0.01$ & $75.32 \pm 0.16$ & $8 \vee .13 \pm 0.23$ \\
\hline
\end{tabular}


Total sugars content in commercial mango, orange and mandarin products were the highest $(80.70$, 82.00 and $81.55 \%$, respectively) compared to oleoresin formulas (78.10, 75.13 and $75.32 \%$, respectively), this may due to the addition of artificial color and aroma, thus be compensated by sugar. Also, total soluble solid (TSS) was higher in mango, orange and mandarin commercial products (96.00, 97.36 and 89.46, respectively) than oleoresin products due to the last products contained natural antioxidants components and essential oil compounds.

Generally, the physical properties such as moisture content, $\mathrm{pH}$, titratible acidity, total sugar and Brix of oleoresin mango, orange and mandarin peels were related to ease of reconstitution.

The bioactive components of mango, orange and mandarin fresh peels oleoresin were tabulated in Table (4). The antioxidative activity of mandarin peels oleoresin must be retained for the observed high phenolic compounds content $(50.51 \pm 2.41 \mathrm{mg} / \mathrm{g})$ and vitamin C (1.30 $\pm 0.06 \mathrm{mg} / \mathrm{g})$ as mentioned in Table (4). While, total flavonoids contents $(5.66 \pm 0.21 \mathrm{mg} / \mathrm{g})$ for mango peels oleoresin showed the second level for tested peels oleoresin oxidative activates, also mango oleoresin was high in carotenoids $(12.53 \pm 0.43 \mathrm{mg} / \mathrm{g})$. Mandarin which has the significant content of essential oil $(1.92 \pm 0.23 \mathrm{~g} / 100 \mathrm{~g})$ comparing to orange and mango oleoresin peels, showed nine terpenoids in observable contents (Table 5).These data were comply to Magda et al. (2008), they found that, mandarin peel had the highest in total phenol content as compared to orange peels (Magda et al., 2008). Ghasemi et al. (2009) reported the total phenolic contents of Citrus reticulate varieties peel powder in the range of 104.2-172.1 $\mathrm{mg} /$ gallic acid.

Table (4): Antioxidant components of mango, orange and mandarin peels oleoresins ( $\mathrm{mg} / \mathrm{g}$ )

\begin{tabular}{lccc}
\hline Items & Mango & Orange & Mandarin \\
\hline $\begin{array}{l}\text { Total } \\
\text { phenols }\end{array}$ & $22.9 \pm 1.09$ & $13.64 \pm 0.44$ & $50.51 \pm 2.41$ \\
$\begin{array}{l}\text { Total } \\
\text { flavonoids }\end{array}$ & $5.66 \pm 0.21$ & $5.11 \pm 0.47$ & $1.65 \pm 0.02$ \\
& & & \\
Carotenoids & $12.53 \pm 0.43$ & $9.06 \pm 0.12$ & $2.14 \pm 0.21$ \\
& & & \\
Vitamin C & $1.02 \pm 0.03$ & $1.22 \pm 0.10$ & $1.30 \pm 0.06$ \\
& & & \\
\hline $\begin{array}{l}\text { Essential oil } \\
\text { (g/100g) }\end{array}$ & $0.05 \pm 0.01$ & $0.36 \pm 0.07$ & $1.92 \pm 0.23$ \\
\hline
\end{tabular}

Values are means of triplicates \pm Standard deviation

\section{Essential oil fractions}

The essential oil fractions of mango, orange and mandarin peels oleoresin were fractionated by GC-MS, the result was showed in Table (5).

Table (5): Essential oil fractions in mango, orange and mandarin peels oleoresins (\%)

\begin{tabular}{|c|c|c|c|}
\hline Items & Mango & Orange & Mandarin \\
\hline$\alpha$ - Thruiene & - & 0.27 & 0.61 \\
\hline$\alpha$-Pinene & 12.82 & 0.53 & 0.98 \\
\hline Camphene & 0.46 & 0.84 & 0.18 \\
\hline Subinene & & 0.35 & 0.29 \\
\hline$\beta$-Pinene & 1.54 & 1.44 & 0.68 \\
\hline Myrcene & 2.30 & 0.82 & 1.33 \\
\hline$\alpha$-Terpinene & 0.33 & 0.75 & 0.96 \\
\hline p-Cymene & 0.38 & 0.26 & 0.65 \\
\hline Limonene & 2.84 & 85.80 & 52.67 \\
\hline 1,8-Cineol & - & - & 13.31 \\
\hline Z- $\beta$-Ocimene & 0.13 & - & - \\
\hline E- $\beta$-Ocimene & - & 0.10 & 6.52 \\
\hline$\gamma$-Terpinene & 0.26 & 0.38 & 11.02 \\
\hline $\begin{array}{l}\text { Cis-Sabinene } \\
\text { hydrate }\end{array}$ & - & 0.32 & 0.18 \\
\hline Octanol & - & 0.09 & 1.12 \\
\hline Terpinolene & 3.14 & 0.98 & 0.13 \\
\hline Linalool & - & 0.43 & 0.71 \\
\hline Camphor & - & 3.62 & 0.44 \\
\hline Terpinene-4-ol & - & 0.28 & 0.02 \\
\hline$\alpha$-Terpinol & - & 0.36 & 1.06 \\
\hline citronellol & - & 0.14 & 0.05 \\
\hline Nerol & - & - & 0.08 \\
\hline Carvacol & - & 0.16 & 0.10 \\
\hline $\begin{array}{l}\text { A-Terpinyl } \\
\text { acetate }\end{array}$ & - & 0.12 & 0.59 \\
\hline Geranyl acetate & - & 0.11 & 0.28 \\
\hline Germacerene D & - & 0.11 & 0.17 \\
\hline Valencene & 0.27 & 0.13 & 0.18 \\
\hline Hexadecanol & 0.28 & - & - \\
\hline 2-Heptadecanoate & 0.12 & - & - \\
\hline
\end{tabular}


Mango peels oleoresin has higher content in $\alpha$ pienene, terpinolene, myrcene and $\beta$-pienene than other fractions $(12.82,3.14,2.30$ and $1.54 \%$, respectively) Also, the major compound in orange then mandarin peels oleoresin was limonene (85.80 and 52.67\%, respectively). Camphor content was higher content in orange than mandarin peels oleoresin (3.62 and $0.44 \%$, respectively). The most important aroma characteristic in mandarin peels oleoresin were 1,8-cineol (13.31\%) followed by $\gamma$-terpinene $(11.02 \%)$ then E- $\beta$-ocimene $(6.52 \%)$.

Conclusively, mandarin followed by mango then orange peels oleoresins contained several essential oil compounds. It's worth to say that the chemical structure has valuable effect at aroma for the effective group and their location on the structure. That gives idea to the valuable activity with the compound concentration in the essential oils.

This data were adapted by Engel and Tressl (1983), who found that Egyptian mango peels cultivar typified by myrcene and limonene. While, limonene was the one most abundant monoterpene, representing in orange (Hashem et al., 2014). Mohamed et al. (2014) also, identified components were thymol, $\alpha$-pinene and $\gamma$-terpinene and linalool in mandarin volatile oils.

\section{Antioxidant activities}

The antioxidant activities of different mango, orange and mandarin peels oleoresin are presented in Table (6). The antioxidant activity for all oleoresin increase gradually by increase oleoresin concentration from 20 to $100 \mathrm{mg}$ oleoresin in different materials. Orange peels oleoresin has the highest antioxidant activity (from 54.20 to $73.00 \%$ ) in gradual concentrations followed by mango peels oleoresin (from 46.24 to $55.82 \%$ ) then mandarin peels oleoresin (from 33.92 to $52.02 \%$ ). These data may be due to that orange peels oleoresin is rich in limonene and camphor, also carotenoids, flavonoids and vitamin $\mathrm{C}$.
Table (6): Antioxidant activities (\%) in different mango, orange and mandarin peels oleoresin concentration (DPPH method)

\begin{tabular}{cccc}
\hline $\begin{array}{l}\text { Oleoresin/ } \\
\text { mg }\end{array}$ & Mango & Orange & Mandarin \\
\hline $\mathbf{2 0}$ & $46.24 \pm 4.54$ & $54.20 \pm 5.20$ & $33.92 \pm 4.32$ \\
$\mathbf{4 0}$ & $48.50 \pm 5.20$ & $58.55 \pm 7.43$ & $38.24 \pm 3.25$ \\
$\mathbf{6 0}$ & $49.08 \pm 4.25$ & $66.53 \pm 6.97$ & $43.54 \pm 5.00$ \\
$\mathbf{8 0}$ & $52.95 \pm 7.34$ & $70.62 \pm 6.32$ & $48.11 \pm 4.85$ \\
$\mathbf{1 0 0}$ & $55.82 \pm 6.55$ & $73.00 \pm 9.64$ & $52.02 \pm 6.23$ \\
\hline
\end{tabular}

Values are means of triplicates \pm Standard deviation.

\section{Organoleptic evaluation}

The organoleptic evaluations of oleoresins from mango, orange and mandarin peels are shown in Tables (7, 8 and 9).

Results in Table (7) revealed no significant difference in color parameter between formulas contained to 80 and $100 \mathrm{mg}$ mango peels oleoresin and commercial formula (8.95, 9.16 and 9.30 , respectively). The maximum score for aroma and flavor were found in mango peels oleoresin products contained 80 and 100 $\mathrm{mg} / 100 \mathrm{~g}$ (9.15 and 9.32; 9.22 and 9.35, respectively), whereas the minimum score was observed in same products which contained 20 and $40 \mathrm{mg} / 100 \mathrm{~g}$ mango peels oleoresin. While, in Table (7) showed no significant difference between all mangos peels oleoresin formulas to commercial products in sweetness and consistency.

Table (7): Organoleptic evaluation mango peels oleoresin products ( $\mathrm{mg} / 100 \mathrm{~g})$ compared with commercial products

\begin{tabular}{|c|c|c|c|c|c|c|}
\hline Items & Color & Sweetness & Aroma & Flavor & Consistency & $\begin{array}{c}\text { Overall } \\
\text { acceptability }\end{array}$ \\
\hline Commercial & $9.30 \pm 0.24^{\mathrm{a}}$ & $9.25 \pm 0.12^{\mathrm{a}}$ & $8.92 \pm 0.26^{\mathrm{a}}$ & $8.20 \pm 1.25^{\mathrm{ab}}$ & $9.50 \pm 0.58^{\mathrm{a}}$ & $9.25 \pm 0.99^{\mathrm{a}}$ \\
\hline 20 & $7.22 \pm 0.76^{\mathrm{c}}$ & $8.94 \pm 0.20^{\mathrm{a}}$ & $7.36 \pm 0.23^{\mathrm{c}}$ & $7.45 \pm 2.05^{\mathrm{c}}$ & $9.45 \pm 0.43^{\mathrm{a}}$ & $8.36 \pm 1.02^{\mathrm{ab}}$ \\
\hline 40 & $7.98 \pm 0.92^{b}$ & $8.96 \pm 0.22^{\mathrm{a}}$ & $8.40 \pm 0.53^{\mathrm{ab}}$ & $7.99 \pm 1.98^{\mathrm{c}}$ & $9.44 \pm 0.23^{\mathrm{a}}$ & $8.55 \pm 1.43^{\mathrm{ab}}$ \\
\hline 60 & $8.00 \pm 1.02^{b}$ & $9.12 \pm 0.28^{\mathrm{a}}$ & $8.86 \pm 0.70^{\mathrm{ab}}$ & $8.54 \pm 0.88^{\mathrm{ab}}$ & $9.43 \pm 0.38^{\mathrm{a}}$ & $8.90 \pm 0.86^{\mathrm{ab}}$ \\
\hline 80 & $8.95 \pm 0.72^{\mathrm{a}}$ & $9.15 \pm 0.24^{\mathrm{a}}$ & $9.15 \pm 0.17^{\mathrm{a}}$ & $9.22 \pm 0.34^{\mathrm{a}}$ & $9.42 \pm 0.41^{\mathrm{a}}$ & $9.40 \pm 0.53^{\mathrm{a}}$ \\
\hline 100 & $9.16 \pm 0.43^{\mathrm{a}}$ & $9.22 \pm 0.17^{\mathrm{a}}$ & $9.32 \pm 0.24^{\mathrm{a}}$ & $9.35 \pm 0.57^{\mathrm{a}}$ & $9.46 \pm 0.55^{\mathrm{a}}$ & $9.42 \pm 0.66^{\mathrm{a}}$ \\
\hline
\end{tabular}


The score for overall acceptability of mango peels oleoresin ranged between 8.36 to 9.42 in all formulas compared with commercial formula, but formula contained 80 and $100 \mathrm{mg} / 100 \mathrm{~g}$ mango peels oleoresin were the best.

In 80 and $100 \mathrm{mg}$ concentrates, there are nonsignificant different between all attributed tested. The overall acceptability, there are non-significant different between commercial formula and formulas containing 80 or $100 \mathrm{mg} / 100 \mathrm{~g}$.
There is gradually increase in score of color, aroma, flavor and overall acceptability in formulas containing 60,80 and $100 \mathrm{mg} / 100 \mathrm{~g}$ orange peels oleoresin observed in Table (8). While, formula containing $100 \mathrm{mg}$ orange peels oleoresin $/ 100 \mathrm{~g}$ was the best in all sensory parameters. The same observation in sweeteners and consistency parameters were not significant difference between all orange peels oleoresin formulas to commercial formula.

Table (8): Organoleptic evaluation of orange peels oleoresin products (mg/100g) compared with commercial products

\begin{tabular}{|c|c|c|c|c|c|c|}
\hline Items & Color & Sweetness & Aroma & Flavor & Consistency & $\begin{array}{c}\text { Overall } \\
\text { acceptability }\end{array}$ \\
\hline Commercial & $9.32 \pm 1.20^{\mathrm{a}}$ & $9.15 \pm 0.16^{\mathrm{a}}$ & $9.23 \pm 1.02^{\mathrm{a}}$ & $8.92 \pm 1.43^{\mathrm{a}}$ & $9.46 \pm 0.52^{\mathrm{a}}$ & $9.30 \pm 1.22^{\mathrm{a}}$ \\
\hline 20 & $8.24 \pm 0.99^{b}$ & $8.84 \pm 0.23^{\mathrm{a}}$ & $7.88 \pm 0.74^{\mathrm{b}}$ & $7.98 \pm 1.20^{\mathrm{c}}$ & $9.48 \pm 0.33^{\mathrm{a}}$ & $8.88 \pm 0.43^{b}$ \\
\hline 40 & $8.55 \pm 1.13^{b}$ & $8.91 \pm 0.32^{\mathrm{a}}$ & $8.25 \pm 0.92^{\mathrm{ab}}$ & $8.40 \pm 1.08^{b}$ & $9.42 \pm 0.20^{\mathrm{a}}$ & $8.92 \pm 0.81^{\mathrm{b}}$ \\
\hline 60 & $9.11 \pm 0.82^{\mathrm{a}}$ & $9.08 \pm 0.30^{\mathrm{a}}$ & $9.18 \pm 0.85^{\mathrm{a}}$ & $9.18 \pm 0.98^{\mathrm{a}}$ & $9.46 \pm 0.41^{\mathrm{a}}$ & $9.11 \pm 0.90^{\mathrm{a}}$ \\
\hline 80 & $9.25 \pm 0.63^{\mathrm{a}}$ & $9.10 \pm 0.22^{\mathrm{a}}$ & $9.22 \pm 0.33^{\mathrm{a}}$ & $9.25 \pm 0.83^{\mathrm{a}}$ & $9.50 \pm 0.37^{\mathrm{a}}$ & $9.20 \pm 0.77^{\mathrm{a}}$ \\
\hline 100 & $9.30 \pm 1.00^{\mathrm{a}}$ & $9.20 \pm 0.14^{\mathrm{a}}$ & $9.30 \pm 0.60^{\mathrm{a}}$ & $9.28 \pm 0.80^{\mathrm{a}}$ & $9.51 \pm 0.52^{\mathrm{a}}$ & $9.32 \pm 0.82^{\mathrm{a}}$ \\
\hline
\end{tabular}

Values are means (10 panelists) \pm Standard deviation

Means within a column (for each variable) marked with letters are significantly different $(\mathrm{P}<0.05)$.

A gradually increases in sensory parameters in formulas containing 60, 80 and $100 \mathrm{mg}$ mandarin peels oleoresin/100g, respectively (Table 9). The maximum score for overall acceptability was observed in formula contained $100 \mathrm{mg}$ of mandarin peels (9.36), then formulas contained 80, 60 and $40 \mathrm{mg}$ mandarin peels oleoresin (9.36, 9.29 and 9.21) respectively, whereas, the minimum score for overall acceptability showed in formula containing $20 \mathrm{mg}$ mandarin peels oleoresin formula.

Table (9): Organoleptic evaluation mandarin peels oleoresin products (mg/100g) compared with commercial products

\begin{tabular}{|c|c|c|c|c|c|c|}
\hline Items & Color & sweetness & Aroma & Flavor & Consistency & $\begin{array}{c}\text { Overall } \\
\text { acceptability }\end{array}$ \\
\hline Commercial & $9.40 \pm 1.00^{\mathrm{a}}$ & $9.24 \pm 0.11^{\mathrm{a}}$ & $9.30 \pm 1.02^{\mathrm{a}}$ & $9.00 \pm 1.20^{\mathrm{a}}$ & $9.51 \pm 0.40^{\mathrm{a}}$ & $9.34 \pm 1.30^{\mathrm{a}}$ \\
\hline 20 & $8.42 \pm 0.62^{b}$ & $8.72 \pm 0.34^{\mathrm{ab}}$ & $8.02 \pm 0.82^{b}$ & $8.03 \pm 1.43^{b}$ & $9.22 \pm 0.83^{\mathrm{a}}$ & $8.76 \pm 1.53^{\mathrm{ab}}$ \\
\hline 40 & $8.69 \pm 0.85^{b}$ & $8.90 \pm 0.80^{\mathrm{ab}}$ & $8.55 \pm 0.64^{\mathrm{ab}}$ & $8.82 \pm 0.85^{\mathrm{ab}}$ & $9.32 \pm 0.90^{\mathrm{a}}$ & $9.05 \pm 0.84^{\mathrm{a}}$ \\
\hline 60 & $9.18 \pm 0.77^{\mathrm{a}}$ & $9.11 \pm 0.64^{\mathrm{a}}$ & $9.26 \pm 0.50^{\mathrm{a}}$ & $9.10 \pm 0.62^{\mathrm{a}}$ & $9.41 \pm 0.73^{\mathrm{a}}$ & $9.21 \pm 0.64^{\mathrm{a}}$ \\
\hline 80 & $9.30 \pm 1.02^{\mathrm{a}}$ & $9.20 \pm 0.88^{\mathrm{a}}$ & $9.50 \pm 0.73^{\mathrm{a}}$ & $9.21 \pm 0.85^{\mathrm{a}}$ & $9.43 \pm 0.81^{\mathrm{a}}$ & $9.29 \pm 0.70^{\mathrm{a}}$ \\
\hline 100 & $9.43 \pm 0.93^{\mathrm{a}}$ & $9.26 \pm 0.69^{\mathrm{a}}$ & $9.53 \pm 0.98^{\mathrm{a}}$ & $9.26 \pm 1.00^{\mathrm{a}}$ & $9.39 \pm 0.66^{\mathrm{a}}$ & $9.36 \pm 0.63^{\mathrm{a}}$ \\
\hline
\end{tabular}


Volatile oil fractions reflect to organoleptic evaluation and consumer attribute. Generally, flavor is the blend of taste and smell perceptions, it is judged to accept food or not. Aroma in mandarin showed the highest one and that due to the quantity of volatile oil (Table 4) and quality of some volatile oil compounds (Table 5). Also, mango and orange gave the highest evaluation in sensory acceptability has been shown for the aroma and flavor results may due to the highest contents in flavonoids and carotenoids and volatile oil components.

\section{CONCLUSION}

Mango, orange and mandarin peel by-products contain many nutritionally and economically valuable components. The by-products from processing industries have significant exploitation potential to produce oleoresins. Therefore, it is capable of offering low-cost nutritional dietary supplement for lower income masses. Economic valorization of peel byproducts could readily be realized through oleoresins flavour utilization instead of synthetic flavours.

\section{REFERENSES}

Abd El-ghfar, A. M. H., H. M. Ibrahim, I. M. Hassan, A. A. Abdel Fattah and Marwa H. Mahmoud (2016). Peels of lemon and orange as valueadded ingredients: Chemical and antioxidant properties. Int. J. Curr. Microbiol. App. Sci., 5(12): 777-794.

Adewole, E., D. F., Adewumi and J. J. Fadaka (2014). Phytochemical constituents and proximate analysis of orange Peel (citrus Fruit). J. Adv. Bot. Zool., 1(3): 1-2.

Ajila, C. M., L. Jaganmohan Rao and U. J. S. Prasada Rao (2010). Characterization of bioactive compounds from raw and ripe Mangifera indica L. peel extracts. Food Chem. Toxicol., 48: 3406-3411.

Ajila, C. M., S. G. Bhat and U. J. S. Prasada Rao (2007). Valuable components of raw and ripe peels from two Indian mango varieties. Food Chem., 102: 1006-1011.

AOAC (2000). Official Methods of Analysis of the Association of Analytical Chemists., $17^{\text {th }}$ ed., edited by Horwitz, AOAC, Washington, DC.

Berardini, N., M. Knodler, A. Scheber and R. Carle (2005). Utilization of mango peels as a source of pectin and polyphenols. Innov. Food Sci. Eng., 6: 442-452.

Boligon, A. A., R. P. Pereira, A. C. Feltrin, M. M. Machado, V. Janovik, J. B. T. Rocha and M. L. Athayde (2009). Antioxidant activities of flavonol derivate from the leaves and stem bark of Scutia buxifolia Reiss. Bioresour. Technol., 100: 6592-6598.

Casquete, R., S. M. Castro, A. Martín, S. Ruiz-Moyano, J. A. Saraiva, M. G. Córdoba and P. Teixeira (2015). Evaluation of the effect of high pressure on total phenolic content, antioxidant and antimicrobial activity of citrus peels. Innov. Food Sci. Emerg. Technol., 31: 37-44.

Chen, M. H. and T. C. Huang (2016). Volatile and nonvolatile constituents and antioxidant capacity of oleoresins in three Taiwan citrus varieties as determined by supercritical fluid extraction. Molecules, 21(12): 1735-1746.

Engel, K. H. and R. Tressl (1983). Studies on the volatile components of two Mango varieties. J. Agric. Food Chem., 31: 796-801.

Ghasemi, K., Y. Ghasemi and M. A. Ebrahimzadeh (2009). Antioxidant activity, phenol and flavonoids contents of 13 citrus species peels and tissues. Pak. J. Pharma. Sci., 22(3): 277281.

Hashem, H. A., A. M. Sharaf, S. A. Amira and G. E. Ibrahim (2014). Changes in physicochemical quality and volatile compounds of orange-carrot juice blends during storage. Food Science and Quality Management, 33:21-35.

IS (2003). Indian Standard (IS-7826)-Specification of ginger oleoresin.

ISO (2009). International Standard Organization (ISO 6571). Spices, condiments and herbsDetermination of volatile oil content (Hydrodistillation method).

Klein, B. P. and A. K. Perry (1982). Ascorbic acid and vitamin A activity in selected vegetables from different geographical areas of the United Sates. J. Food Sci., 47: 941-945.

Magda, R. A., A. M. Awadand K. A. Selim (2008). Evaluation of mandarin and navel orange peels as natural sources of antioxidant in biscuits. Alex J. Food Sci. Tech., (Special Volume Conference): 75-82.

Masuko, T., A. Minami, N. Iwasaki, T. Majima, S. Nishimaru and Y. Lee (2005). Carbohydrate analysis by a phenol-sulfuric acid method in microplate format. Analytical Biochem., 339: 69-72.

Mohamed, A. S., A. M. Hussein and G. E. Ibrahim (2014). Physicochemical, sensorial, antioxidant and volatile of juice from prickly pear with guava or mandarin. Inter. J. Food and Nutr. Sci., 3 (6): 44-53.

Mondello, L., A. Casilli, P. A. Tranchida, R. Costa, P. Dugo and G. Dugo (2004). Fast GC for the analysis of citrus oils. J. of Chromatographic Sci., 42: 410-416.

Manjarres-Pinzon, K., M. Cortes-Rodriguezand E. Rodríguez-Sandoval (2013). Effect of drying conditions on the physical properties of impregnated orange peel. Brazilian J. Chemical Engineering, 30 (3): 667-676.

Nagata, M. and I. Yamashita (1992). Simple method for simultaneous determinations of chlorophyll and carotenoids in tomato fruit. Nippon Shokuhin Kogyo Gakkaish, 39 (10): 925928. (Barros et al., 2006, Food Chem., 103: 413-419).

Orozco, R. S., P. B. Hernandez, G. R. Morales, F. U. Nunez, J. O. Villafuerte, V. L. Lugo, N. F. 
Ramirez, C. E. Diaz and P. C. Vazquer (2014). Characterization of lignocellulosic fruit waste as an alternative of feedstock for bioethanol production. BioResurces, 9 (2): 1873-1884.

Palmeria, S. M. V., L. M. Goisand L. D. Souza (2012). Extraction of phenolic compounds from mango peels. Latin Am. Appl. Res., 42: 7781.

Pharmacopeia (1989). The state Pharmacopeia of USSR, Moscow, 2: 324-334. (C.F., Food Chem., 85: 2004, 231-237).

Puligundla, P., V. S. R. Obulam, S. E. Oh and C. Mok (2014). Biotechnological potentialities and valorization of mango peel waste: A Review. Sains Malaysiana, 43(12): 1901-1906.

Ranganna, S. (2005). Handbook of analysis and quality control for fruit and vegetables products. Tata Mc Graw Hill Publishing Co. Ltd, New Delhi, India.

Ruiz, C., C. Ramirez, Gutierrezde de Pineres, M. Angulo and J. Hedreira (2011). Obtaining and characterization of mango peel powder and its use as a source of fiber and a functional ingredient in natural yogurt.
Proceeding of the $11^{\text {th }}$ Inter. Congress on Eng. and Food (ICEF 11).

Solis-Solis H. M., M. C. Santoyo, S. S. Galito, G. L. Solano and J. A. R. Sanchez (2007). Characterization of aroma potential of apricot varieties using different extraction techniques. Food Chemi., 105: 829-837.

SPSS (2000). Statistical package for social sciences. SPSS for windows version 19, SPSS Inc., Chicago, IL, USA.

Tuormaa, T. E. (1994). The Adverse Effects of Food Additives on Health: A Review of the Literature with Special Emphasis on Childhood Hyperactivity. J. Orthomolecular Med., 9 (4): 225-243.

Wetungu, M. W., P. K. Tarus, F. K. Segor, X. Cheseto and M. V. O. Omolo (2015). Essential oil chemistry of some Mangifera indica varieties from Kenya. Amer. J. Essential Oils and Natural Products, 3(2): 01-06.

Yen, G. C. and H. Y. Chen (1995). Antioxidant activity of various tea extracts in relation to their antimutagenicity, J. Agric. Food Chem., 43: 27-32.

\title{
الراتنجات الزيتية لقشور الماتجو والبرتقال واليوسفي لإعداد مشروبات نكهة طبيعية وصحية
}

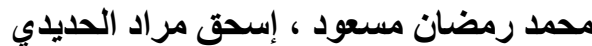 \\ معهد بحوث تكنولوجيا الأغذية ـ- مركز البحوث الزيدر اعية ـ ألجيزة مصر.
}

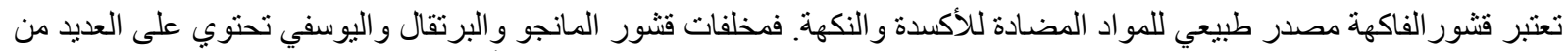

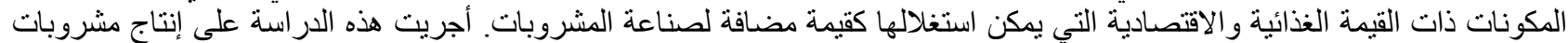

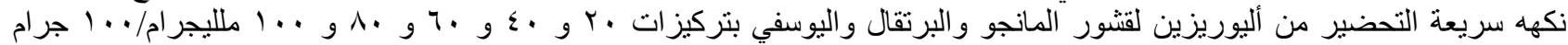

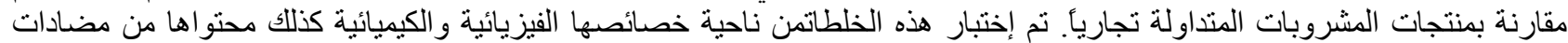

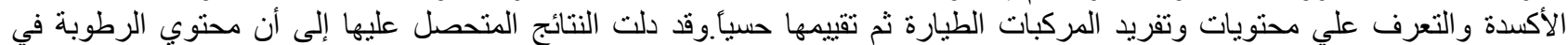

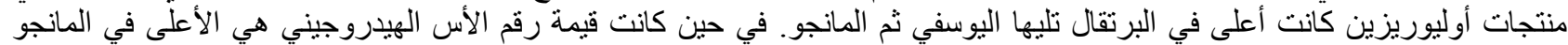

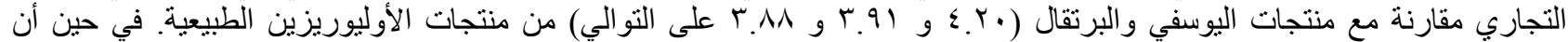

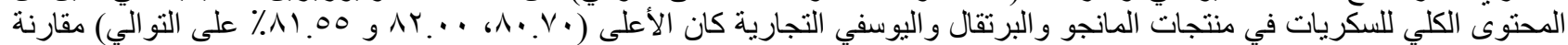

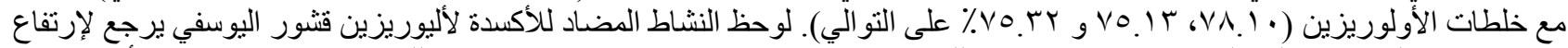

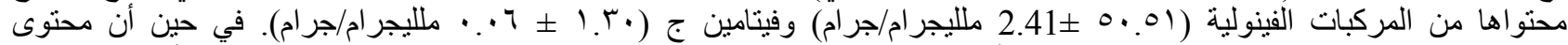

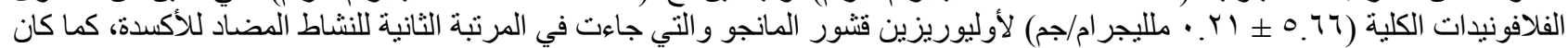

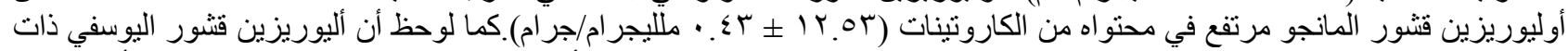

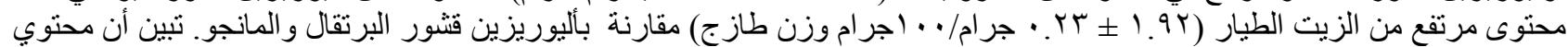

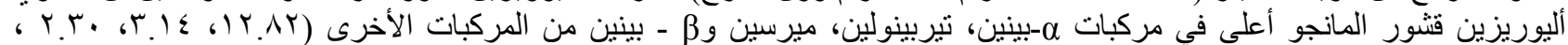

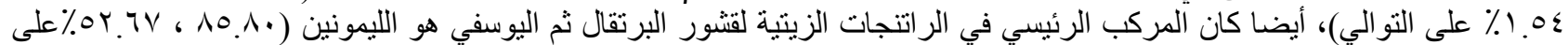

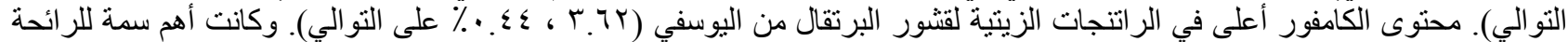

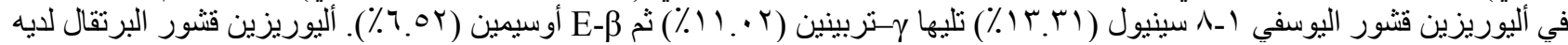

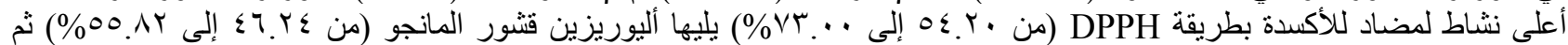

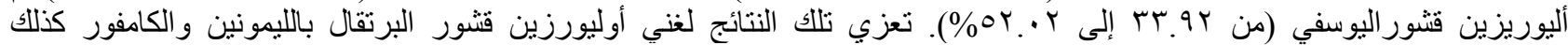

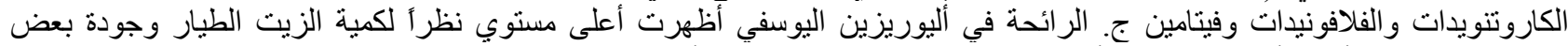

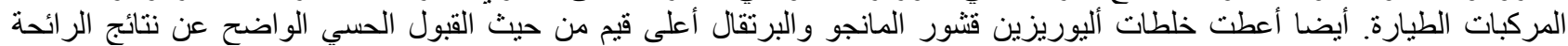

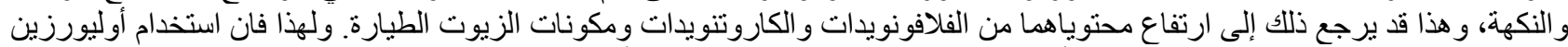

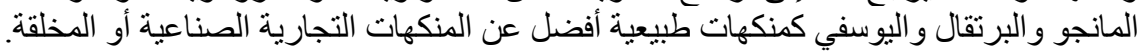

